\title{
MITTEFORMAALÕPE PRAKTIKUTE KEELEKASUTUSES
}

\author{
HALLIKI PÕLDA, \\ RIINA REINSALU, KATRIN KARU
}

\begin{abstract}
Annotatsioon. Artiklis arutleme Eesti haridusvaldkonna kesksete mõistete formaal-, informaal- ja mitteformaalõppe - sisu üle ja võtame neist fookusesse viimase. Selgitame välja mitteformaalõppe mõiste tunnused praktikute keelekasutuses ning analüüsime, kuidas väljenduvad peamised tunnused mitteformaalõppe omasõnalistes terminivariantides. Analüüsitavaks materjaliks on kuus fookusrühma intervjuud eri valdkondade mitteformaalõppe praktikutega. Kvalitatiivsel sisuanalüüsil ilmnesid mitteformaalõppe oluliste tunnustena õppija vastutus eesmärkide seadmisel, tema sisemine motivatsioon ja autonoomsus, variatiivsed õpikeskkonnad ja -protsessid, juhendaja kui toetaja roll ning õppeprotsessi suunatus õppija arengule. Neist mitmed annavad ainest mitteformaalõppe terminivariantide käsitlemiseks, aga ka laiemaks diskussiooniks kolme mõiste eristamise vajalikkuse üle.
\end{abstract}

Võtmesõnad: haridussõnavara, formaalõpe, informaalõpe, vabaõpe, termin, mõiste

\section{Sissejuhatus}

Üleilmastumisest ja ühiskonna pidevast muutumisest tingituna on järjest lisandunud uusi mõisteid ning nende võõrsõnalisi tähistajaid. Nii on jätkuvalt aktuaalne otsida ka uusi, sealhulgas omasõnalisi termineid ja arutleda olemasolevate sobivuse üle. Just uued teadusuuringud ja nende arvukad tulemused on aluseks, miks teadlased püüavad leida oma publikatsioonides mõistetele parimaid vasteid ning vaidlevad kasutatavate terminite sisu üle (Kerge 2011: 92). On ju mistahes teadusharus teadmiseni jõudmise eeldus täpne mõistestik (Mereste 2000; Nemvalts 2020b).

Eestikeelne terminivara vajab hoolt ja korrastamist ning valdkondade terminitarvitus uurimist. See kehtib ka haridusvaldkonna kohta. 
Haridusterminite mitmetähenduslikkusele, keelelisele ebakorrektsusele ja mitmete terminite sobimatusele on viidanud paljud (nt Lepajõe 2014; Kuurme 2020; Nemvalts 2020a). Nende n-ö probleemsete haridusterminite hulka kuulub ka 2020. aasta lõpuni kehtiva haridusstrateegia (EEÕS 2014) ja kavandatava strateegia (Valk 2019) keskne termin mitteformaalõpe koos formaalõppe ja informaalöppega (vt arutelu Karu jt 2019; Nemvalts 2020a), nagu on tavaks õpet Euroopa haridussüsteemis ja -terminoloogias jaotada (Saar jt 2014: 4; UNESCO 2020: 8).

Vaatlusalune terminikolmik on ingliskeelsetes poliitikadokumentides tähistanud mõisteid, mis märgivad eri õppetüüpe, ja jõudnud sealt eestikeelsetesse hariduspoliitilistesse tekstidesse, sedakaudu ka meie avalikku keelekasutusse. Seesugune terminite tõlkimine mõnest Euroopa Liidu suurkeelest (tavaliselt inglise või prantsuse, harvem saksa keelest) on levinud praktika. Sageli tehakse seda valdkonna teadlastega aru pidamata ja eriala terminoloogidega koostöös parimaid omakeelseid vasteid otsimata. Marju Lepajõe (2014: 1542) noomibki oma rahvuslikkusele keskenduvas essees, et hariduspoliitikas, eeskätt kõrghariduspoliitikas, ei mõisteta emakeelse kõrghariduse olulisust. Tuletagem siinkohal meelde ka Krista Kerge kirjutisi õiguskeeletõlgete kohta, milles ta toob esile, kui tähtis on termineid mitte otse tõlkida, vaid võõrkeelseid tekste mõtestada, kasutades täpsemaid omasõnalisi vasteid. „Tuleks olla väga järjekindel arusaamas, et Eestile pole kohustuslik mitte Brüsseli või Luxemburgi tõlgete keel, vaid tõlgitud tekstide mõte," rõhutab Kerge (2010: 147). Katrin Halliku ja Katre Kasemetsa sõnul (2017: 5) on aga mitmetahulisele mõistele head terminit raske leida. Euroopa Liidu tekste eestindades lähenetakse mõistetele enamasti tõlkepõhiselt (Paemurd 2017: 53), ehkki eelistada tuleks süstemaatilist ehk valdkonnapõhist terminitööd (Kesküla 2017: 49). Paraku ongi ingliskeelsed formal, non-formal ja informal learning Eestis kasutust leidnud toortõlgetena, kuigi nende omasõnalisi vasteid võib leida nii üldkeele sõnaraamatutest kui ka valdkonna oskussõnastikest (nt HKS).

\section{Formaal-, mitteformaal- ja informaalõpe kui hariduse kesksed mõisted}

Formaal-, mitteformaal- ja informaalõppe eristamine on hariduspoliitilistes ja -teaduslikes tekstides levinuim õppimise liigitus. Samas tekib küsimus, miks sellist eristamist üldse oluliseks peetakse. Põhjusi tuleb 
otsida minevikust. Nimelt on aastasadu tuntud eelkõige formaalhariduse mõistet, mis viitab formaalses ${ }^{1}$ ehk ametlikus õppeasutuses organiseeritult toimuvale õppele (Autio jt 2013: 70).

Formaalõpe tähistab lasteaias, koolis või ülikoolis õppekavade alusel korraldatud eesmärgistatud õpet, mis toimub kvalifitseeritud õpetajate juhendamisel ning milles hinnatakse õpiprotsessi ja selle tulemusi (EEÕS: 22; Saar jt 2014: 4). Formaalõpet seostatakse nii lapse- kui ka täiskasvanueas õppimisega. Seevastu informaalõpe on palju uuem termin. Informaalõpe on õppija seisukohast lähtudes eesmärgistamata õpe, mis toimub igapäevaelu situatsioonides ning mille tulemused ei ole õppijale enamasti kohe näha (EEÕS: 22). Seetõttu on haridusteadlased informaalõpet kirjeldanud kui formaalõppe ,vaest sugulast“ (Golding jt 2009: 34). Mõiste ise on ajalooliselt alguse saanud just täiskasvanu õppimise ja elukestva, sh töökohapõhise õppe kontekstis (Collins, Kapur 2014) ning termini võttis 1950. aastal ilmunud teoses „Informal adult education“ kasutusele täiskasvanuhariduse teerajaja Malcolm Knowles (Le Clus 2011). 1960ndatel tähistati sedasama mõistet aga terminiga iseõpetamine (ingl self-teaching), mis viitas täiskasvanu õppimisele ilma õpetaja toeta ja õppeprotsessi hindamiseta (Tough 1967: 4). Seejuures võib informaalõpe olla tahtlik või tahtmatu, toimuda väga erinevates keskkondades, leida aset nii üksi kui ka rühmas, olla tajutud või alateadlik ning algatatud indiviidi, kogukonna või ühiskonna poolt (McGivney 1999: 1).

Mitteformaalõpe asub eelkirjeldatud kahe õppetüübi vahel, st tal on nii formaal- kui ka informaalõppe tunnused (Malcolm jt 2003: 314). Mõiste ise tuli haridusvaldkonda juba sadakond aastat tagasi, kui haridus muutus inimeste isikliku ja tööelu lahutamatuks osaks ning Euroopa ja Ameerika haridussüsteemis otsiti võimalusi täiendõppeks: ülikoolide ja instituutide juurde tekkisid avatud kursused; Londoni ülikool andis 19. sajandi lõpul ka ametliku kraadi mitteformaalõppes (Holmberg 1986: 6). Mõiste mitteformaalõpe levis laiemalt 1960ndatest ${ }^{2}$ reaktsioonina formaalhariduses sätestatud piiridele ning tähistas paindlikku, õppija vajadustest lähtuvat õpet

1 Eesti keele seletav sõnaraamat annab sõnale formaalne mitu tähendust: 1) sisulise tähtsuseta, ainult vormitäiteks tehtud v. olemasolev; ametlik, paberlik, mittetegelik; 2) vormist lähtuv, vormiline (EKSS). Just selline mitmetähenduslikkus on põhjus, miks terminoloogide arvates on terminikolmik sobimatu (vt Nemvalts 2020a).

2 Täpsustus: terminit mitteformaalõpe kasutati esimest korda UNESCO 1957. aasta haridusraportis (Colley jt 2003: 10). 
(Dudzinska-Przesmitzki, Grenier 2008: 11), mis ühendab informaalõppele omase iseõppimise, autonoomsuse ja enesejuhitavuse ning formaalõppe institutsioonid ja kogukonnad (Colley jt 2003: 8, 9). Haridusvaldkonnas on siiani kasutusel Philip Coombsi ja Manzoor Ahmedi (1974: 8) kümnenditetagune definitsioon, mille kohaselt on mitteformaalõpe eesmärgistatud ja vabatahtlik ning toimub organiseeritult, kuid väljaspool koolikeskkonda ja elukestvalt. Samas rõhutatakse tänapäeval üha enam, et oluline on õppetüüpe mitte eristada ja vastandada, vaid leida elemendid või tunnused, mis õppijat toetavad (Colley jt 2003: 64, 65; UNESCO 2020: 8). Mitteformaalõppega seotult tuuaksegi esile õppija autonoomsus ning rõhutatakse juhendaja toetajarolli (Knowles jt 2015: 40, 253).

Eestis on mitteformaalõpet defineeritud kui vabatahtlikku õpet, mis leiab aset väljaspool kooli ja eri keskkondades ning on ette võetud teadlikult eesmärgiga end arendada. Mitteformaalõppe läbiviijad võivad olla nii professionaalsed koolitajad kui ka näiteks vabatahtlikud või omaealised. (EEÕS: 23) Märkimisväärne on aga see, et Eesti kavandatavas haridusstrateegias mitteformaalõpet ei defineerita, vaid seatakse strateegiliseks eesmärgiks vähendada eraldusjooni, mis ,takistavad liikumist formaal-, mitteformaal- ja informaalõppe ning ka üld- ja kutsehariduse vahel““ (HTM 2020: 11).

Eelnevast nähtub, et mõisted on kasutusele tulnud eri aegadel ja kultuurikontekstides ning seega pole tekkinud terviklikku süsteemi. Mõistekolmik ise pärineb 1970ndatest, kui haridust hakati funktsioonide ja formaliseerituse alusel nii liigitama (Karu jt 2019), seda esmalt hariduspoliitilistes tekstides, kust see kandus haridusteadlaste keelekasutusse ja haridusuuringute oskussõnavarasse ning selle kaudu ka praktikute kõnepruuki. Kuigi valdkonna teadlased ja sõnaraamatud (hariduse ja kasvatuse sõnaraamat, haridusleksikon jt) on välja pakkunud omasõnalisi terminivariante, on toortõlkelised terminid praktikas enam kasutust leidnud (vt arutelu haridusteaduste termini üle Kuurme 2020: 806). Sellist olukorda põhjendab Ülle Sihver (2018: 63-64) terminikomisjonide töö eripäraga: terminiarutelu ingliskeelse termini või selle toorlaenu kasutuse üle toimub siis, kui kasutajale on eesti keelde sobimatu vorm juba omaseks saanud. Sama on juhtunud ka vaatlusaluste terminitega. Lisaks on haridussüsteem ja arusaamad õppest aastate jooksul nii palju teisenenud (vrd EEÕS), et tekib taas vajadus vaadelda nende mõistete erinevusi ja ühisosa praegusaegse haridusstrateegia valguses (vt HTM 2020: 11). 
Eeltoodut arvestades on tähtis käsitleda formaal-, mitteformaal- ja informaalõppe tunnuseid ja mõistete seoseid nii sisu- kui ka keeletasandil ning arutleda väljakujunenud mõistesüsteemi otstarbekuse üle. Kuna artikkel on osa laiemast uurimusest, mille keskmes on mitteformaalõppe tähendus praktikas, siis keskendume ka praegusel juhul mitteformaalõppele, sh terminite rööpsusest ja mitmetähenduslikkusest tulenevatele probleemidele. Seetõttu on uuringu eesmärk selgitada mitteformaalõppe põhimõtete elluviijate ehk praktikute arusaamade põhjal välja mitteformaalõppe mõiste tunnused ja hinnata, kuidas need peegelduvad kasutatavates terminites. Eesmärgi täitmiseks otsime vastust järgmistele küsimustele: 1) mis tunnuste kaudu iseloomustavad praktikud mitteformaalõpet; 2) kuidas väljenduvad mitteformaalõppele omased tunnused selle terminivariantides? Kuna praktikas konstrueeritakse mitteformaalõpet seostatuna formaal- ja informaalõppega, osutame artiklis ka mõistete seostele.

\section{Formaal-, mitteformaal- ja informaalõpe terminimoodustuse vaatenurgast}

Terminite moodustamiseks kasutatakse eesti keeles olemasolevat või võõrast keelest laenatud ainest. Teistest keeltest laenamise tulemusena jõuavad keelde viit liiki laenud: tsitaat-, päris-, tõlke- ja tähenduslaenud ning laenlühenditega moodustatud liitsõnad. (Erelt 2007: 207-209) Formaal-, mitteformaal- ja informaalõpe, mis on üle võetud inglise keelest, esindavad võõrsõnalisi pärislaene. Kuigi võõrsõnalistesse laenudesse on eri aegadel suhtutud vastandlikult, valitseb Eesti terminitöös siiski arusaam, et tähtis on leida tasakaal oma ja võõra vahel: omi ja võõraid termineid peab olema soodsas vahekorras kõrvuti (samas: 133). See aga ei tähenda, et võõrsõna tuleks pimesi eelistada. Võõrterminid on mõnel juhul otstarbekad, kuid tähtis on teada nende tähendust ja hinnata nende sobivust eesti keele süsteemi (Nemvalts 2011: 149). Võõruse-omasuse asemel tuleb lähtuda sisulisest täpsusest ja stiililisest sobivusest (Mereste 2000: 219). Selline lähtekoht on iseäranis asjakohane tänapäevases teadusmaailmas, kus laenamisest on saanud peamine terminimoodustusviis ja võõrsõnalistest terminitest pigem reegel kui erand.

Et ka võõrtermin täidaks oma eesmärki võimalikult hästi, peab ta vastama nn hea termini põhikriteeriumidele ehk olema ühemõtteline, 
läbipaistev, süsteemne ja ökonoomne ning kooskõlas keelenormiga. Lisaks peetakse tähtsaks ajakohasust: kui keelevälistel või -sisestel põhjustel, sh nüüdisnormiga vastuolu tõttu, termin enam ei sobi, on aeg see välja vahetada või seda kohendada (Erelt 2007: 301-302). Ajakohasuse kriteerium haakub ka sotsiokognitiivse terminiteooria aluspõhimõttega, mille kohaselt arenevad mõistmine ja seega ka mõistmisüksused (resp. mõisted) pidevalt (Temmerman 2000: 74). Niisamuti rõhutatakse olulise kriteeriumina prestiižsust, sest isegi kui termin vastab kõigile eelnimetatud põhikriteeriumidele, võib juhtuda, et see ei ole keelekasutajatele siiski meelepärane ega lähe seetõttu käibele (Tavast, Taukar 2013: 140). Seega tuleb terminiloomes hoolikalt kaalutleda, millele rõhk panna, et termin osutuks otstarbekohaseks.

Terminikolmik formaal-, mitteformaal-ja informaalõpe (vahel ka kujul formaalne, mitteformaalne ja informaalne õpe) on mitmeti probleemne. Kuigi haridusvaldkonnas on käsitletavad terminid tugevasti juurdunud ja nende mõistesisu asjatundjatele (sh praktikutele) tuttav, siis avalikkus nende sisu üheselt ei mõista, sest neil jääb puudu läbipaistvusest ehk motiveeritusest - terminite väliskuju ei peegelda nende aluseks olevaid mõisteid. Ühelt poolt on raskusi sõnaga formaalne, mis tuleneb ladina sõnast formalis 'vormiline; vormist lähtuv; sisulise tähtsuseta, vormitäiteks tehtud' (VL 2012: 335) ning tekitab küsimuse, mis see vorm on ja kas see on põhitunnus, millest nende terminite puhul lähtuda (vt ka allmärkus 1 $1 \mathrm{k} 240$ ). Teisalt raskendab mitteformaal- ja informaalõppe seostamist nende aluseks olevate mõistetega samatähenduslike eesliidete kasutamine: kuna ladina liite in- eestikeelne vaste on mitte- või eba- (samas: 454), ei ole mitteformaal- ja informaalõppe mõistet võimalik terminite alusel eristada. Sellele probleemile on varem viidatud nii meil (Karu jt 2019) kui ka mujal (Malcolm jt 2003).

Läbipaistmatute võõrsõnaliste terminite formaal-, mitteformaal- ja informaalõpe asemele on pakutud omasõnalisi. Hariduse ja kasvatuse sõnaraamat formaalõpet ei sisalda, kuid haridussõnastikus on eelisterminina esitatud kooliõpe (HS), mis osutab eeskätt õppimiskohale, kuid formaalõppel endal stiilimärgend puudub. Seevastu mitteformaalne õpe on märgendatud sõnaraamatus sobimatuks keelendiks, mille asemel tuleks kasutada vabaõpet (HKS: 285), mis annab aimu õppimise vabatahtlikkusest või õppetööga kaasnevast vabadusest. Niisamuti kannab halva stiili märgendit informaalõpe, mille asenduseks soovitatakse terminit 
kogemusõpe (samas: 152), et rõhutada õppe kogemuslikku poolt. Veebisõnastikku on rööpvariandina märgitud ka juhuõpe (HS), mis osutab õppimise juhuslikkusele, eesmärgistamatusele.

Hoolimata sõnastiku soovitustest pole võõrsõnaline kolmik oma positsiooni omasõnadele loovutanud, mis võib tähendada, et omasõnaliste vastete jaoks valitud tunnused ei kajasta mõistet piisavalt täpselt. Keerukust lisab ka asjaolu, et ühiskond ja haridussüsteem ühes sellega on aja jooksul mõnevõrra muutunud. Tekib küsimus, mis on käsitletavate mõistete peamised tunnused, millest tuleks terminite moodustamisel lähtuda.

\section{Uurimismaterjal ja meetod}

2019. a sügisel tehti projekti TA/2719 „Mitteformaalõppe tähendused praktikute ja praktikate vaates“ raames 17 fookusrühmaintervjuud 64 praktikuga, kes viivad ellu mitteformaalõppe põhimõtteid. Praktikud esindasid täiskasvanuhariduse (TKH), noorsootöö (NT), kultuuri (K), heaolu (H), majanduse (M) ja keskkonnahariduse (KK) valdkonda. Materjali kogumisel eelistati rühmaintervjuusid, kuna praktikute omavaheline suhtlus intervjuu ajal aitas genereerida rohkem ja variatiivsemat uurimismaterjali, kui individuaalintervjuudes oleks avaldunud, ning soodustas mitteformaalõppe kohta rikkalike kirjelduste saamist (vt Stewart jt 2007: 19-31).

Intervjuud koosnesid neljast osast, millest esimeses, häälestusosas paluti osalejatel kirjeldada mitteformaalõpet kaasavõetud foto abil. Ülejäänud kolm osa olid pühendatud vastavalt mitteformaalõppe tähendusele, rakendamisele ja tulevikuperspektiividele. Et optimeerida valimi hulka, kuid kajastada siiski eri valdkondade praktikute seisukohti, valisime analüüsimiseks iga valdkonna esimese intervjuu (ühe intervjuu pikkus 18-29 lk), mis väljendasid 21 praktiku arusaamu. Transkribeeritud materjali eritledes märkasime, et sisuanalüüsi koodid hakkasid korduma, seega õigustas selline optimeerimine end igati.

Intervjuusid analüüsisime kvalitatiivse sisuanalüüsi meetodil (vt Saldaña 2012). Esmalt jagasime transkriptsioonid omavahel võrdselt ära, nii et iga uurija sai kaks intervjuud, ja kandsime ühistabelisse induktiivselt, st andmetest lähtudes loodud koodid ehk uurimiseesmärgi seisukohast tähenduslikud üksused (mitteformaalõppe tunnused) koos tekstikatketega. Seejärel arutasime kõik koodid üheskoos läbi ning koondasime need $(n=567)$ tähenduse alusel 29 alakategooriasse, mille 
ühisosa põhjal moodustusid kaheksa põhikategooriat. Kui alakategooria osutus unikaalseks ja ühegi teise alakategooriaga ei haakunud, nimetasime selle põhikategooriaks (nt „Eesmärk“). Nii joonistusid kodeerimise, kategoriseerimise, kategooriate kirjeldamise ja korduskategoriseerimise tulemusena välja lõplikud kategooriad (vt tabel).

Tabel. Sisuanalüüsi kategooriate jaotus

\begin{tabular}{|c|c|c|}
\hline $\begin{array}{l}\text { Põhikategooriad } \\
\text { ja koodide arv }\end{array}$ & $\begin{array}{c}\text { Alakategooriad } \\
\text { ja koodide arv }\end{array}$ & Alakategooriaid ilmestavad tekstinäited \\
\hline Eesmärk (47) & Eesmärk (47) & $\begin{array}{l}\text { Mingil eesmärgil kindlasti see nagu } \\
\text { toimub. }(\mathrm{H})\end{array}$ \\
\hline \multirow[t]{2}{*}{$\begin{array}{l}\text { Motivatsioon } \\
(58)\end{array}$} & $\begin{array}{l}\text { Sisemine } \\
\text { motivatsioon } \\
(51)\end{array}$ & $\begin{array}{l}\text { Sisemine motivatsioon või jõud käivitab } \\
\text { selle, et ma tahan seda selgeks saada. (M) }\end{array}$ \\
\hline & $\begin{array}{l}\text { Väline } \\
\text { motivatsioon (7) }\end{array}$ & $\begin{array}{l}\text { Mul võibolla ei ole motivatsiooni minna } \\
\text { oppima, aga see on seadusega minu } \\
\text { valdkonnas ette nähtud. }(\mathrm{TH})\end{array}$ \\
\hline \multirow[t]{2}{*}{ Areng (46) } & $\begin{array}{l}\text { Eneseanalüüs } \\
(25)\end{array}$ & $\begin{array}{l}\text { Ta pärast analüüsib, et mis see tulem on. } \\
\text { (NT) }\end{array}$ \\
\hline & Eneseareng (21) & Mitteformaalõpe kui eneseareng. (TH) \\
\hline \multirow[t]{5}{*}{$\begin{array}{l}\text { Keskkond } \\
(100)\end{array}$} & $\begin{array}{l}\text { Füüsiline } \\
\text { keskkond (40) }\end{array}$ & $\begin{array}{l}\text { See ei pea toimuma tavapärases } \\
\text { klassiruumis. }(\mathrm{M})\end{array}$ \\
\hline & $\begin{array}{l}\text { Vaimne } \\
\text { keskkond (18) }\end{array}$ & $\begin{array}{l}\text { Ta pingutab, pärast tunneb sellest rõõmu, } \\
\text { see on eduelamus ju. }(\mathrm{K})\end{array}$ \\
\hline & $\begin{array}{l}\text { Sotsiaalne } \\
\text { keskkond (10) }\end{array}$ & Seal toimus ka reaalne eluline suhtlus. (M) \\
\hline & $\begin{array}{l}\text { Digikeskkond } \\
\text { (2) }\end{array}$ & $\begin{array}{l}\text { Sa lähedki YouTube’i ja õpidki sealt ise } \\
\text { mingi oskuse või asja või võtad e-kursuse. } \\
\text { (M) }\end{array}$ \\
\hline & Avarus (30) & $\begin{array}{l}\text { Tegelikult ei tea kunagi, kuhu see välja viib } \\
\text { või tagasi toob. }(\mathrm{TH})\end{array}$ \\
\hline \multirow[t]{3}{*}{$\begin{array}{l}\text { Õppeprotsess } \\
(164)\end{array}$} & Meetod (39) & $\begin{array}{l}\text { Kasutatakse aktiivõppe meetodeid, } \\
\text { osalusopet, teistsuguseid tehnikaid ja } \\
\text { meetodeid. (M) }\end{array}$ \\
\hline & $\begin{array}{l}\text { Juhendamine } \\
(27)\end{array}$ & $\begin{array}{l}\text { Juhin seda noortegruppi soovitud suunas. } \\
\text { (NT) }\end{array}$ \\
\hline & $\begin{array}{l}\text { Õppijakesksus } \\
\text { (19) }\end{array}$ & $\begin{array}{l}\text { Mitteformaalse õppe keskmes on inimene. } \\
(\mathrm{KK})\end{array}$ \\
\hline
\end{tabular}




\begin{tabular}{|c|c|c|}
\hline $\begin{array}{l}\text { Põhikategooriad } \\
\text { ja koodide arv }\end{array}$ & $\begin{array}{c}\text { Alakategooriad } \\
\text { ja koodide arv }\end{array}$ & Alakategooriaid ilmestavad tekstinäited \\
\hline & $\begin{array}{l}\text { Rakendatavus } \\
(18)\end{array}$ & $\begin{array}{l}\text { Mitteformaalses óppes saad sa seda } \\
\text { rakendada, neid teadmisi. (KK) }\end{array}$ \\
\hline & Tulemused (18) & $\begin{array}{l}\text { Mis on üks väga suur stiimul, on see } \\
\text { resultaat. }(\mathrm{K})\end{array}$ \\
\hline & Tegevused (14) & $\begin{array}{l}\text { Selline kogukonda panustamine või selline } \\
\text { kodanikualgatus ja keskkonnahoid. (M) }\end{array}$ \\
\hline & Valdkond (13) & $\begin{array}{l}\text { Hea mitteformaalne õpe, kus on mingi } \\
\text { teema, mingi valdkond. }(\mathrm{M})\end{array}$ \\
\hline & $\begin{array}{l}\text { Loomingulisus } \\
(12)\end{array}$ & Õpe võib ollagi loov protsess. $(\mathrm{KK})$ \\
\hline & Eeskuju (4) & $\begin{array}{l}\text { Eeskujud panevad nad [orppijad] ka kaasa } \\
\text { tulema, tegema, olema ja edasi tahtma. }(\mathrm{K})\end{array}$ \\
\hline \multirow[t]{4}{*}{$\begin{array}{l}\text { Osalemine } \\
(46)\end{array}$} & $\begin{array}{l}\text { Vabatahtlikkus } \\
\text { (18) }\end{array}$ & $\begin{array}{l}\text { Mitteformaalne on kindlasti vabatahtlik, et } \\
\text { see on vabatahtlik. (KK) }\end{array}$ \\
\hline & Kaasatus (15) & $\begin{array}{l}\text { Mitteformaalne on siis, kui osalejad on } \\
\text { aktiivselt kaasatud sellesse ôppeprotsessi. } \\
\text { (M) }\end{array}$ \\
\hline & Avatus (7) & $\begin{array}{l}\text { Nad rohkem avatud oleksid ja kui sa oled } \\
\text { avatud, siis sa ju võtad ka vastu rohkem. (K) }\end{array}$ \\
\hline & Vastutus (6) & $\begin{array}{l}\text { Mitteformaalhariduses ongi see ôppija ise } \\
\text { juba selle vastutuse võtnud. }(\mathrm{TH})\end{array}$ \\
\hline \multirow[t]{4}{*}{$\begin{array}{l}\text { Omandamine } \\
(58)\end{array}$} & $\begin{array}{l}\text { Kogemused } \\
(28)\end{array}$ & $\begin{array}{l}\text { Kindlasti seal [mitteformaalõppes] on hästi } \\
\text { oluline kogemuslik aspekt juures. }(\mathrm{H})\end{array}$ \\
\hline & $\begin{array}{l}\text { Üldpädevused } \\
\text { (14) }\end{array}$ & $\begin{array}{l}\text { Mund oskused, et mida sa saad seal, } \\
\text { suhtlemisoskused, mida sa saad koos seal } \\
\text { teistega arendada. (M) }\end{array}$ \\
\hline & Teadmised (12) & $\begin{array}{l}\text { Ehedas looduses omandada } \\
\text { keskkonnahariduslikku teadmist ja õppida } \\
\text { loodust tundma. (KK) }\end{array}$ \\
\hline & Oskused (4) & $\begin{array}{l}\text { Nad said täiendatud mingite oskuste võrra. } \\
\text { (NT) }\end{array}$ \\
\hline \multirow[t]{2}{*}{$\begin{array}{l}\text { Õppekorraldus } \\
\text { (48) }\end{array}$} & $\begin{array}{l}\text { Tingimused } \\
\text { (39) }\end{array}$ & $\begin{array}{l}\text { Ei pea nii nagu struktureeritud ja } \\
\text { reglementeeritud ja nii edasi olema, } \\
\text { vabam. (M) }\end{array}$ \\
\hline & $\begin{array}{l}\text { Kinnitus läbi- } \\
\text { mise kohta (9) }\end{array}$ & $\begin{array}{l}\text { Sellel }[M F \tilde{O}-l] \text { on kindel eesmärk, aga sul ei } \\
\text { ole nagu mingit tunnistust või paberit. }(\mathrm{H})\end{array}$ \\
\hline
\end{tabular}


Kodeerimise käigus tegime peale sisuliste tähelepanekute märkmeid keelekasutuse kohta, mille kaudu konstrueeritakse samuti tähendusi. Eritähelepanu pöörasime mitteformaalõppe seostele formaal- ja informaalõppega ning terminikasutusele (oma- vs. võõrterminid). Järgnevalt kirjeldame tulemusi uurimisküsimuste kaupa, tuues esmalt esile mitteformaalõppe mõiste tunnused ja seejärel nende avaldumise omasõnalistes terminivariantides.

\section{Mitteformaalõppe tunnused}

Analüüsitud intervjuudest ilmnes mitteformaalõppe ühe põhikategooriana eesmärk. Kuigi eesmärki mainitakse sageli üldsõnaliselt (eesmärgistatud; eesmärgipärane), rõhutatakse niisama tihti seda, et õppes osaleja on eesmärgi ise seadnud (ta teab, mida tahab) ja otsustab ise, kuidas seda saavutada (igaühel on oma tee, mismoodi ta siis selle eesmärgini jõuab). Samas peeti oluliseks ka õppija ja juhendaja koostööd eesmärkide seadmisel ning saavutamisel (ühiste eesmärkide seadmine). Kui mitteformaalõpe toimub töökeskkonnas, on tähtis arvestada lisaks asutuse üldiste eesmärkidega. Samuti võivad eesmärgid tuleneda õppekavast (nagu formaalõppeski).

Intervjueeritavate sõnul on just eesmärk see, mis eristab mitteformaalõpet informaalsest - informaalõpe on eesmärgistamata õpe. Vastanduse kaudu mainiti, et mitteformaalõppe eesmärk peab olema seatud õppe alguses (1). Eesmärgi puudumist seostatakse juhuslikkusega (2).

(1) Tal [informaalõppel] ei ole eesmärki alguses, et ta on nagu vabas keskkonnas kõikjal õppimine ... nad ei teagi, et nad õpivad tegelikult. (NT)

(2) Teisest küljest võibolla on ka selline juhuslikkus, et ma võibolla olen ka siin täna juhuslikult ja ma õpin informaalselt. (TH)

Motivatsiooni põhikategooria toob esile õppes osalemise sisemised (õppijast lähtuvad) ja välised (keskkonnast ja suhetest sõltuvad) motivaatorid. Sisemine motivatsioon esines sagedasti mõiste huvi kujul, rinnastus sõnadega ja ja või viitab tunnuste omavahelisele tihedale seosele. Sisemist motivatsiooni kirjeldati õppija tegevusvõimekuse, subjektsuse ja enesejuhitavuse kaudu. Õppijal on vaba tahe, initsiatiiv, soov ja valmisolek (mitteformaal)õppes aktiivselt osaleda, sellesse panustada ja seeläbi areneda ning ta leiab selleks ka vajalikud ressursid (koht, raha, aeg). Ta ei vaja otseselt ei teiste soovitusi ega riiklikke regulatsioone, et teadmisi omandada. 
Näide (3) ilmestabki, et õppimine ei ole iseeneslik protsess (iseenesest ei ladestu), vaid lähtub eesmärgi kõrval ka sisemisest vajadusest ja huvist õppimise vastu (sisemine motivatsioon või jõud käivitab), millega juhendaja arvestab (ikka saan õpilase huvist lähtuda).

(3) Mitteformaalõpe ei ole see, mis ladestub elu jooksul iseenesest, tal on ikkagi eesmärk, et see huvi või motivatsioon sellel õppijal peab olema. /.../ sisemine motivatsioon või jõud käivitab selle, et ma tahan selgeks saada, et nagu iseenesest ei ladestu. (M)

Selgus, et sisemine motivatsioon mitteformaalõppe tunnusena on üks eristumise aluseid: formaalõpet iseloomustab välise, mitteformaalõpet seevastu sisemise motivatsiooni olemasolu (4).

(4) See [õppimine] on seotud motivatsiooniga /.../ formaalõppes keegi ju ei küsi su käest, kas sa tahad või ei taha, et nii kaua kui sa oled koolikohustuslik, nii kaua sa pead käima, aga mitteformaalõpet sa ikkagi võtad juurde mingisugusest enda initsiatiivist või soovist. $(\mathrm{H})$

Ka areng mitteformaalõppe tunnusena avaldus õppija subjektsuses. Õppimist konstrueeritakse enesearengu võimalusena ja eneseanalüüsi peetakse oluliseks tegevuseks, mille kaudu seda toetada. Räägitakse nii tööalasest enesetäiendamisest kui ka üldisest silmaringi avardamisest. Õppimisele lisandub määramatuse dimensioon (5). Eneseanalüüsis nähakse võimalust seda määramatust leevendada, samuti õpitut teadvustada ja seoseid luua (6).

(5) Mitteformaalõpe kui eneseareng, tihtipeale me ei tea, kuhu me selle kõigega välja jõuame. (TH)

(6) Mõnikord veel tähtsam on selle reflekteerimine, pärast arusaamine, et mida siis tehti. $(\mathrm{H})$

(7) Mingil hetkel peab siis kas suunatult või õppija poolt see teadvustamise pool olema. (M)

Näide (7) ilmestab eritelul ilmnenut: arengu toetamisel on oluline nii juhendaja kui ka õppija enese roll. Sellisel moel avaldub mitteformaalõppes sotsiaalsete suhete ja keskkonna tähtsus.

Keskkond oligi üks mitteformaalõppe põhikategooria. Intervjuude vastustes sisaldusid õpikeskkonna eri dimensioonid: füüsiline, sotsiaalne, vaimne ja digitaalne. Enim pöörati tähelepanu füüsilisele keskkonnale: mitteformaalõpet eristab formaalsest just õppe toimumine teistsuguses 
(vabamas) füüsilises ruumis, kui seda on koolikeskkond. Rõhutatakse, et fookus on õppe sisul, mitte vormil (8). Selline arusaam võimaldab lõimida mitteformaalõpet formaalõppesse, nagu selgub näitest (9). Lisaks kirjeldati mitteformaalõpet õuesõppe ja töökohapõhise õppe kontekstis, mis on ajalooliselt olnud seotud pigem informaalõppega.

(8) See ei pea toimuma tavapärases klassiruumis /... / Ma ei pea käima just selles majas, nendes õppeklassides, kus kõik on sisustatud, kus on olemas tehnika, kus on olemas pabertahvlid, et tegelikult ma võin õppida ka keldris, kui see õppe sisu on selline, et ma ei vaja tegelikult neid vahendeid. (M)

(9) Ei pea tingimata olema väljaspool klassiruumi, see võib ka tegelikult olla formaalõppega seotud, ruumid võivad samad olla. (KK)

Füüsilise keskkonna kõrval avaldus sotsiaalne keskkond, mille keskmes on õppe osaliste sotsiaalsed suhted ja koostöö (näites (10) töökohapõhise õppe kontekstis), ning vaimne keskkond, mis peegeldas õppija (positiivseid) emotsioone - rõõmu, rahulolu ja õppekeskkonna turvalisust (11). Marginaalne oli digikeskkonna osa, mis avaldus kogu uurimismaterjalis vaid kahel korral ning viitas veebiõppe rohketele ja variatiivsetele võimalustele.

(10) Lähen kolleegi ruumi ja kolleeg õpetab. (M)

(11) Kui tal ei olnud tore, siis ta võib iga kell ka seda välja öelda. (KK)

Õpikeskkonna dimensioonide ülesena esines avaruse alakategooria. See näitab, et mitteformaalõpe toimub (klassikalisest) õppekeskkonnast või -korraldusest, mistahes süsteemist väljaspool, pakub õppimiseks väga erinevaid võimalusi ning soodustab osaliste loovat mõtlemist ja tegutsemist (12).

(12) Mitteformaalõpe on ükskõik milline kujutluspilt väljaspool koolitundi. $(\mathrm{K})$

Peale keskkonna seostati avarust ka õppeprotsessiga, millest kujunes üks mitteformaalõppe tunnuseid ja millel oli arvukalt alakategooriaid - üheksa. Enim kirjeldati õppeprotsessi eri meetodite kaudu, sh nimetati aktiivõppe ja suhtlemisega seotud, aga ka mängulisi meetodeid (13).

(13) Kõige esimene meetod, mis meelde tuli, oli diskussioon, arutelu, refleksioon, rühmatööd, kus peab grupis mingi kindla teema kallal olema, filmilinastused, mis siis on, et on ekspert, käib, toimub arutelu, 
diskussioon. Mis veel? Rollimängud, simulatsioonid, mingid pildikesed tegelikkuses, $n-0 ̈$ eneseavamine. (KK)

Juhendamine õppeprotsessi osana viitab nii tegijale kui ka tegevusele. Tegija on juhendaja ja koolitaja - ükskõik kes (ka naabrinaine), peaasi et ta on õpetamisel professionaalne. Täiskasvanuhariduse ja heaolu rajal välditi sõna õpetaja, et vastanduda formaalharidusele (14).

(14) Formaalhariduses on õpetaja või keegi ekspert, kes siis annab teadmisi edasi /. . . Mitteformaalõppes koolitaja ja juhendaja ei peagi andma valmis lahendusi, et nende [õppijate] seas on spetsialiste, palju pädevamaid inimesi. (TH)

Õppeprotsessi keskmesse seadsid vastanud inimese, kelle stardipositsioon on erinev. Erinev on ka tema õppimise rütm, mida tuleb austada ja mille järgi oma tegevust kohandada. Mitteformaalõppe keskmes on ka teadmiste rakendamine, sest õpe on praktiline ja eluline. Õppija jaoks on stiimuliks resultaat, kuid õpe ei ole võistlus, sest õppijate saavutused on erinevad. Tulemuste mõõdikuks on pigem õppijate rahulolu, ei hinnata sooritust, samas peavad tulemused olema kõrgetasemelised (15).

(15) Harrastusteater ei tohi teha halba teatrit. /.../ See, kuidas see tegemine [muudab] mind või tegijat, see tundub mulle olevat väga oluline ja sellepärast alandust ei tee. $(\mathrm{K})$

Mitteformaalõppe tunnustena nimetati õppeprotsessis veel tegevusi, valdkonda, loomingulisust ja eeskuju. Loominguline protsess võimaldab vastanduda standardsele õppele, kasutada loovust ja mängulisust. Eeskujuks on õppeprotsessis oskaja või teadja, kelle järgi juhinduda ning kes kaasab teisi.

Osalemine mitteformaalõppes avaldus vabatahtlikkuse ja kaasatusena. Areng toimub õppija omal soovil ja just vabatahtlik, mitte sunnitud ega kohustuslik osalemine loob eeldused selleks, et õppijad panustavad õppeprotsessi, on kaasatud (16) ning vastutavad oma õppimise ja hariduse eest (17).

(16) Sinna [mitteformaalõppesse] tulevadki need, kes sellest asjast ise huvituvad ja löövad kaasa ja teadlikult ennast selles arendavad. (K)

(17) Et ta õpib iseendale ja millal ta hakkab aru saama, kus ta õpib, ja just see vastutuse koht, et kui, et ta ise algatab, organiseerib ja saab aru, et ta ise vastutab oma hariduse või harituse eest. (KK) 
Omandamine tähendab nii kogemuste, teadmiste kui ka oskuste täiendamist. Lisaks omandatakse selliseid üldpädevusi (18), mis ei ole seotud otseselt õppe eesmärkidega, näiteks suhtlemis-, esinemis- ja meeskonnatööoskused ning väärtushinnangud.

(18) Mitteformaalõpe on see koht, kus hästi palju sotsiaalseid oskusi tekib, et esinemisoskus või suhtlemisoskus. (H)

Õppekorralduses eristusid regulatiivsed tingimused. Ühelt poolt seostuvad need õppija vabadusega osaleda õppes (eeltingimusi ei ole), seda olenemata vanusest (vanusepiire seal ka pole). See viitab mitteformaalõppe seosele elukestva õppega. Samas võib osalust piirata mitteformaalõppe tasulisus (võib osutuda kulukaks või kalliks). Teisalt on mitteformaalõpe seotud aga juhendaja vabadusega korraldada õpet viisil, mis tundub eesmärki silmas pidades kõige otstarbekam (vabas vormis; anda vabad $k \ddot{a} e d$ ). Tingimustega seostub kinnitus õppe läbimise kohta, mis esitati eituse kaudu (19).

(19) Samas ta võib olla kohustuslik, kui me võtame kooli suhtes, ta võiks olla kohustuslik, aga tal ei ole nagu seda tunnistust, /.../ et sul ei ole tõendit paberi peal, et sa selle ära tegid. $(\mathrm{H})$

Kuigi praktikud väärtustavad seda, et mitteformaalõpe pole nii tugevasti reguleeritud kui formaalõpe, kus tuleb lähtuda õppekavast (ei ole nii rangetes raamides; ei lähtu ju mingist kavast või kirja pandud ja ette antud reeglitest), leiab osa neist siiski, et mitteformaalõppel peaks olema õppekavas kindel koht. Nagu ilmneb ka näitest (19), peaks mitteformaalõpe olema kohustuslik, kuid õppijal tuleb võimaldada valida, mida ja kuidas ta õpib.

\section{Mitteformaalõpet tähistavad terminid}

Fookusrühma intervjuu teine plokk sisaldas küsimust mitteformaalõppe omasõnalise vaste vabaõpe kohta. Soovisime teada, mis assotsiatsioone vabaõpe praktikutes tekitab.

Osa praktikute jaoks seostus vabaõpe valikuvabaduse ja vabatahtlikkusega (20), aga ka avatuse ja loomingulisusega, mis on mitteformaalõppe olulised tunnused, ning nad pidasid vabaõpet mitteformaalõppe sünonüümina sobivaks. Teine osa väljendas aga arvamust, et vabaõpe 
tekitab väärseoseid vabahariduse ja -kasvatusega, samuti vabaühenduste ja -ainetega. Iroonilised (vabakasvatamatus) ja naljatlevad väljendid (tilulilu, ludri-mudri) viitavad, et terminisse vabaõpe ei suhtuta tõsiselt. Lisaks assotsieerus vabaõpe Waldorfi kooliga, kus on vabam kord, kuid kuna ka sealne õpe on reguleeritud õppekavaga, jäid osalejad vabaduse suhtes eriarvamusele. Eelnimetatud assotsiatsioonide tõttu ei peetud terminit vabaõpe sobivaks. Seevastu kolmas osa praktikuid seostas vabaõpet hoopis informaalõppega, kus tähtsal kohal on kogemused ja juhuslikkus (21).

(20) Vaba õpe positiivses tähenduses, et ta on ikkagi seesama vaba, et tuleb sinu enda vabast tahtest ja soovist, et sul on see mingi soov midagi õppida ja omandada. Vaba ka selles viisis, kuidas see toimub, kus see toimub, kellega toimub. (M)

(21) Vabaõpe võib olla on nagu see mõiste, mis tähistab seda n-ö mittesihipärast õppimist $/ . . . /$ mingit teist, ilma eesmärgita õppimist või kogemata. (KK)

Peale vabaõppe käsitlesid praktikud ka muid omasõnu. Mitmel korral mainiti sõna kogemusõpe, soovides osutada kogemusele kui ühele mitteformaalõppe olulisele tunnusele. Teadlikumalt pakuti välja sõna huviharidus (resp. huviõpe), kuid kõheldi selle sobivuses. Eeskuju otsiti varasemast sõnaühendist tunni-ja klassiväline tegevus, vihjates, et sellest annaks tuletada koolivälise õppe (vastandiks formaal- ehk kooliõppele). Kõik need mainingud olid põgusad ja ei viinud üksikasjaliku aruteluni.

Intervjuudest käisid läbi ka sõnad eneseharidus ja lisaõpe, kuid nagu näidetest (22) ja (23) näha, peeti nende all silmas hoopis informaalõpet, sest rõhutati õppe juhuslikkust.

(22) Äkki „eneseharidus“? / ... Teen, et mina muutuks targemaks. Ma kas õpin seda arvutit või lähen mängin klaverit või kannelt või ükskõik mis asju. Või tulen teatrisse ja harin ennast. (K)

(23) / .../ et siis see lisaõpe peaks andma neid lisaomadusi ja -eeldusi. (K)

Kuna uuringu fookuses oli mitteformaalõpe, siis muudele õppetüüpidele omasõnalisi vasteid ei otsitud. Vaid ühes intervjuus anti hinnang, et sõnad formaalne ja mitteformaalne on kehvad, ning pakuti intervjueerija ettepaneku peale formaalhariduse vasteks kooliharidus ja mitteformaalhariduse vasteks eneseharidus (vt näide 22). Teises intervjuus nimetati formaalõpet normaalõppeks, kuid taas jäi mõttearendus poolikuks. 


\section{Arutelu tunnuste ja terminite üle}

Uuringust selgus, et mitteformaalõpet konstrueeritakse endiselt formaalõppele vastandumise kaudu, nagu see on ajalooliselt välja kujunenud (vt Coombs, Ahmed 1974; Malcolm jt 2003). Vastandumine avaldub kõigis kaheksas põhikategoorias ja pea kõigi alakategooriatena kirjeldatud tunnustes, nt erinev eesmärgiseade, fookus sisemisel motivatsioonil, eristuv keskkond ja teistsugune õppeprotsessi korraldus. Muu hulgas tuleb vastandumine selgelt esile õpetaja rolli kirjeldamisel: formaalhariduses on õpetaja teadmiste edasiandja või ekspert, mitteformaalõppes toetaja (vrd Knowles jt 2015).

Kõigil põhikategooriatel on olemas vähemalt osaline kattuvus nii informaal- kui ka formaalõppega, mis osutab, et praktikas on õppetüübid üksteisele lähenenud. Formaal-, mitteformaal- ja informaalõppe põimimise vajadusele viidatakse ka uutes strateegiadokumentides (HTM 2020; UNESCO 2020). Mitteformaalõppe eripära avaldub aga ilmnenud alakategooriates: mitteformaalõpet iseloomustavad õppija sisemine motivatsioon ja autonoomsus, variatiivsed õpikeskkonnad ja -protsessid ning juhendaja kui toetaja roll (vrd Malcolm jt 2003; Knowles jt 2015). Mitteformaalõppes keskendutakse teadlikult õppija arengule ja selle toetamisele, mis on ka haridusstrateegia fookuses (EEÕS; Valk 2019).

Mõneti ootamatuna tuli analüüsi tulemusena esile omandamise tunnus, sest nüüdisaegsed õppimisteooriad räägivad omandamise asemel pigem kogemuspõhiste teadmiste konstrueerimisest (HTM 2017: 9). See võib viidata õppe toimumisele loomulikus keskkonnas (nt keeleõpe), nagu keskkond mitteformaalõppe tunnusena uuringus avaldus (nt avatus, piiramatud valikuvõimalused). Analüüsi tulemusena ilmnenud mahukaima kategooria, õppeprotsessi keelelised konstruktsioonid viitavad samuti õppijast lähtuvale käsitlusele. Praktikud rõhutasid õppijakesksust ja seda toetavate meetodite kasutamist, loomingulisust, õpitu rakendatavust ja ülekandmise vajalikkust. Mitteformaalõpe eristub teistest õppetüüpidest selle poolest, et toetab õppija eesmärkide seadmist ja iseõppimist ning rõhutab eeskujude potentsiaali õppimise korraldamisel.

Mõiste tunnused on tähtsad ka terminiloome seisukohast. Kuna terminilt eeldatakse muu hulgas tähenduslikku läbipaistvust ehk motiveeritust, on tähtis, et ta tooks mõiste tunnuseid piisavalt esile (Erelt 2007: 72). 
Kuigi fookusrühma intervjuudes keskenduti mitteformaalõppele, annavad mitteformaalõppe tunnused ja nende vastandamine teiste õppetüüpide tunnustele ainest aruteluks mitte ainult mitteformaalõppe, vaid ka formaalja informaalõppe omasõnaliste vastete üle.

Hariduse ja kasvatuse sõnaraamatu järgi tuleks mitteformaalõppe asemel kasutada vabaõpet (HKS 2012: 285). Kuigi sõna vaba seostub vabatahtlikkusega, mis ilmnes mitteformaalõppe olemusliku tunnusena ka teadusallikatest (vt nt Coombs, Ahmed 1974), on sel ka muid tähendusi, mis hõlmavad praeguse uuringu järgi peale vabatahtliku osalemise ka õppekorraldust ja -protsessi ning motivatsiooni. Esiletõstmist väärib, et vabatahtlikkust (ja laiemalt vabadust) praktikud teiste õppetüüpidega ei seostanud, mistõttu võib seda pidada motiveeritud tunnuseks. Kuna mitteformaalõpe on terminina laialdaselt levinud ja loomulikustunud, suhtusid praktikud omasõnalisse terminisse vabaõpe võõristavalt, kuigi samas mööndi, et vabaõppega harjumine vajab aega ja enam avalikku selgitust.

Haridussõnastikus eelistatakse formaalõppele kooliõpet (HS). Kuigi osa praktikuid väljendas arvamust, et formaalõpe toimub koolis ja mitteformaalõpe väljaspool kooli, oldi valdavalt siiski seisukohal, et keskkonna alusel ei saa õppetüüpidel vahet teha, nt võidakse ka huvikoolis rakendada formaalõpet ja üldhariduskoolis mitteformaalõpet. Niisamuti leiti, et mitteformaal- ja formaalõppe eristamisel ei peaks tänapäeval lähtuma sellest, kas õpe toimub õppekava alusel. Kuna kool ei määra ei koha ega institutsioonina õppe olemust, on kooliõpe tähenduslikult eksitav. Lisaks raskendab kooliõppe kasutuselevõttu selle mitmetähenduslikkus, sest see on tähenduses 'lapse õppimine ja õpetamine koolis' kasutusel ka koduõppe vastandina (HKS: 218).

Informaalõppe omasõnalisteks vasteteks on haridussõnastikus kogemusõpe ja juhuõpe (HS). Kuna kogemuste omandamine ja vahetamine moodustavad keskse osa mitteformaalõppest ning praktikud kasutasid mitteformaalõppe iseloomustamiseks sõna kogemusõpe, ei ole kogemus tunnus, mis võimaldaks õppetüüpe eristada. Lisaks näitab lihtne veebiotsing, et kogemusõpet kasutatakse ingliskeelse termini experiential learning vastena, mitte traditsioonilise mitteformaalõppe tähenduses. Juhuõppe vastu räägib küll vähene kasutussagedus, kuid kuna see on terminina haridussõnastikus hiljem välja pakutud, pole sel olnud juurdumiseks aega. Juhuõppe kasutuspotentsiaalile viitab aga asjaolu, et haridusteadlased on 
hakanud seda tasapisi kasutama ja selle sobivuse üle arutlema, eelistades seda kogemusõppele (vt Teder 2019: 32). Kuidas termin juurdub praktikute keelekasutuses, vajaks edasist uurimist.

Uuringutulemuste tõlgendamisel on oluline meeles pidada, et järelduste tegemist võib mõjutada kvalitatiivanalüüsi eripära mitte taotleda üldkehtivaid järeldusi, vaid peegeldada inimeste kogemusi lahutamatuna nende üldisest keelekogemusest. Kindlasti suunab tulemusi ka see, et intervjuuküsimused sisaldasid mitteformaalõpet. Samas olid küsimused avatud ja nii said intervjueeritavad mõiste sisu vabalt käsitleda: mõiste tunnused avaldusid nende keelevalikutes hoolimata küsimuste keelevalikutest.

Kuna artikli aluseks olev uuring on üksnes mitteformaalõppe kohta, vajaks kõigi kolme õppetüübi mõiste ja terminivariantide, sh võõr- ja omasõnaliste vastete analüüs lisauuringut. Arvestades, et formaal-ja mitteformaalõpet hakati eristama 1970ndatel ning viiekümne aasta jooksul on haridusteaduslikud põhimõtted nii meil kui mujal tugevasti muutunud, võib arvata, et need muutused on mõjutanud ka mõistesüsteemi. Tekib küsimus, kas senine kolmikjaotus on jätkuvalt asjakohane või tuleks piirduda kaksikjaotusega, jättes kõrvale informaalõppe kui eesmärgistamata õppe. Veelgi enam, kuna formaal-ja mitteformaalõppe tunnused kattuvad vähemalt osaliselt ning õppetüüpide piirid (sh keskkondade vahel) on hägustunud, seab see formaal- ja mitteformaalõppe eristamise vajaduse kahtluse alla. Sellise strateegilise eesmärgi püstitab ka Eesti uus haridusstrateegia (HTM 2020: 11).

Siinne mitteformaalõppe tunnuste uuring osutab võimalusele, et oleme jõudnud või jõudmas aega, kus meil on nii koolis kui ka väljaspool kooli üks õpe, milles osaleja seab mingite üldiste eesmärkide raames endale individuaalseid eesmärke, et suurendada enda huvi teadmiste ja oskuste, aga eeskätt kogemuste omandamise vastu. Sellise õppe korraldaja on traditsioonilise õpetaja rolli asemel võtnud endale toetaja rolli, et soodustada õppija aktiivset osalemist õppes, jättes vastutuse õppimise eest siiski õppijale. 


\section{Kirjandus}

Autio, Tero, Tiiu Kuurme, Rain Mikser 2013. Haridus. - Haridusleksikon. Toim. Rain Mikser. Eesti Keele Sihtasutus, 69-77.

Colley, Helen, Phil Hodkinson, Janice Malcom 2003. Informality and Formality in Learning: A Report for the Learning and Skills Research Centre. University of Leeds. https://kar.kent.ac.uk/4647/3/Informality $\% 20$ and $\% 20$ Formality\%20in\%20Learning.pdf (18.12.2020).

Collins, Allan, Manu Kapur 2014. Cognitive apprenticeship. - The Cambridge Handbook of the Learning Sciences (2nd ed.). Ed. by R. Keith Sawyer. Cambridge: Cambridge University Press, 109-126. https://doi. org/10.1017/CBO9781139519526.008

Coombs, Philip H., Manzoor Ahmed 1974. Attacking Rural Poverty: How Nonformal Education Can Help. Baltimore, London: The John Hopkins University Press.

Dudzinska-Przesmitzki, Dana, Robin S. Grenier 2008. Nonformal and informal adult learning in museums. - Journal of Museum Education 33 (1), 9-22. https://doi.org/10.1080/10598650.2008.11510583

EEÕS = Eesti elukestva õppe strateegia 2020. Haridus- ja Teadusministeerium, Eesti Koostöö Kogu, Eesti Haridusfoorum. https://www.hm.ee/sites/ default/files/strateegia2020.pdf (18.12.2020).

EKSS = Margit Langemets, Mai Tiits, Tiia Valdre, Leidi Veskis, Ülle Viks, Piret Voll 2009. Eesti keele seletav sõnaraamat. Eesti Keele Instituut. Tallinn: Eesti Keele Sihtasutus. https://www.eki.ee/dict/ekss/ (18.12.2020).

Erelt, Tiiu 2007. Terminiõpetus. Tartu: Tartu Ülikooli Kirjastus.

Golding, Barry, Mike Brown, Annette Foley 2009. Informal learning: A discussion around defining and researching its breadth and importance. Australian Journal of Adult Learning 49 (1), 34-56.

Hallik, Katrin, Katre Kasemets (koost., toim.) 2017. Tõlkimise tahud. Tallinn: EKSA. eurokeelehoole.eki.ee/documents/compendiums/4de1c86bf768 725c5edc18c87f84098f.pdf (02.03.2021).

HKS = Tiiu Erelt, Mari Kadakas, Ulve Kala-Arvisto, Inger Kraav, Viivi Maanso, Helin Puksand, Eva Tamm, Inge Unt 2012. Hariduse ja kasvatuse sõnaraamat. Toim. Tiiu Erelt. Tallinn: Eesti Keele Sihtasutus.

Holmberg, Börje 1986. Growth and Structure of Distance Education. London: Croom Helm.

HS = Haridussõnastik. http://www.eki.ee/dict/haridus/index.cgi.

HTM 2017 = Õpikäsitusest ja selle muutumisest. Elukestva õppe strateegia 2020 1. eesmärgi selgitused. Haridus- ja Teadusministeerium. https:// www.hm.ee/sites/default/files/har_min_broshyyr_12lk_est_veebi.pdf (22.12.2020). 
HTM 2020 = Haridusvaldkonna arengukava 2021-2035. Haridus- ja Teadusministeerium. https://www.hm.ee/sites/default/files/haridusvaldkonna arengukava_2035_29.10.2020_riigikokku.pdf (02.03.2021).

Karu, Katrin, Larissa Jõgi, Ilona-Evelyn Rannala, Triin Roosalu, Lianne Teder, Halliki Põlda 2019. Mitteformaalõppe tähenduse konstrueerimine poliitikadokumentides. - Eesti Haridusteaduste Ajakiri 7 (1), 50-75. https://doi.org/10.12697/eha.2019.7.1.03

Kerge, Krista 2010. Muutustest õigusdiskursuses ja keeles. - Õiguskeel 1, $146-152$.

Kerge, Krista 2011. Tõlkevõhik keele- ja lugemisoskuse valdkonna terminivarast. - Eesti teaduskeel ja terminikorrastus. Toim. Peep Nemvalts. (= Tallinna Ülikooli eesti keele ja kultuuri instituudi toimetised 13.) Tallinn: Tallinna Ülikool, 91-133.

Kesküla, Kaisa 2017. Mis on mõistel pistmist terminiga? - Tõlkimise tahud. Toim. Katrin Hallik, Katre Kasemets. Tallinn: EKSA, 44-51.

Knowles, Malcolm S., Elwood F. Holton III, Richard A. Swanson 2015. The Adult Learner: The Definitive Classic in Adult Education and Human Resource Development (8th ed.). Abingdon: Routledge. http://dx.doi. org/10.4324/9781315816951

Kuurme, Tiiu 2020. Tõmbetuuled ja tõmbekeeled uues haridusest kõnelevas sõnavaras. - Akadeemia 5, 799-825.

Le Clus, Megan A. 2011. Informal learning in the workplace: A review of the literature. - Australian Journal of Adult Learning 51 (2), 355-373. https:// ro.ecu.edu.au/ecuworks2011/153/ (22.12.2020).

Lepajõe, Marju 2014. Milleks rahvuslikkusele tõlkimine. - Akadeemia 9, 1539-1549.

Malcolm, Janice, Phil Hodkinson, Helen Colley 2003. The interrelationships between informal and formal learning. - Journal of Workplace Learning 15 (7/8), 313-318. https://doi.org/10.1108/13665620310504783

McGivney, Veronica 1999. Informal Learning in the Community: A Trigger for Change and Development. Leicester: National Institute for Adult Continuing Education.

Mereste, Uno 2000. Oskuskeel ja seaduste keeleline rüü. Artikleid ja lühiuurimusi. Tallinn: Eesti Keele Sihtasutus.

Nemvalts, Peep 2011. Terminiteadusest eesti teaduskeeleni. - Eesti teaduskeel ja terminikorrastus. Toim. Peep Nemvalts. (= Tallinna Ülikooli eesti keele ja kultuuri instituudi toimetised 13.) Tallinn: Tallinna Ülikool, 136-171.

Nemvalts, Peep 2020a. Haridus formaalse väljundamise distantsil. - Õpetajate Leht, 11. detsember. https://opleht.ee/2020/12/haridus-formaalsevaljundamise-distantsil/ (20.12.2020). 
Nemvalts, Peep 2020b. Rahvuse mõistestikku tähistav terminivara. - Eesti teaduskeel keelterikkas teadusmaailmas. Toim. Peep Nemvalts. (= Acta Universitatis Tallinnensis. TLÜ teaduskeelekeskuse köide 2.) Tallinn: Tallinna Ülikooli Kirjastus, 130-167.

Paemurd, Elice 2017. Terminitööst Euroopa Komisjonis ja laiemalt. - Tõlkimise tahud. Toim. Katrin Hallik, Katre Kasemets. Tallinn: EKSA, 52-59.

Saar, Ellu, Marge Unt, Kristina Lindemann, Epp Reiska, Auni Tamm 2014. Oskused ja elukestev õpe: kellelt ja mida on Eestil oskuste parandamiseks õppida? PIAAC uuringu temaatiline aruanne nr 2. Tartu: Haridus- ja Teadusministeerium. https://dspace.ut.ee/handle/10062/44229 (02.03.2021).

Saldaña, Johnny 2012. The Coding Manual for Qualitative Researchers (2nd ed.). Sage Publications.

Sihver, Ülle 2018. Eestikeelse terminivara hoole ja kasutus on terminoloogiakomisjoni eesmärk ja mõte. - Oma Keel 1, 62-66.

Stewart, David W., Prem N. Shamdasani, Deniss W. Rook 2007. Focus Groups: Theory and Practice (2nd ed.). (= Applied Social Research Methods Series 20.) Sage Publications. https://dx.doi.org/10.4135/9781412991841

Tavast, Arvi, Marju Taukar 2013. Mitmekeelne oskussuhtlus. Tallinn: Valgus.

Teder, Lianne 2019. Noortetöö on noortega, noorsootöö noorte põlvkonnaga. Mõtestades noorsootööd ja noorsootöötaja rolli. Noorsootöö artiklite kogumik. Toim. Tanja Dibou, Ilona-Evelyn Rannala. Tallinn: Tallinna Ülikool, 28-45.

Temmerman, Rita 2000. Towards New Ways of Terminology Description: The Sociocognitive Approach. Amsterdam: John Benjamins. http://dx.doi. org/10.1075/tlrp.3

Tough, Allen 1967. Learning without a Teacher: A Study of Tasks and Assistance during Adult Self-Teaching Projects. Toronto: Ontario Institute for Studies in Education.

UNESCO 2020 = Embracing a Culture of Lifelong Learning: Contribution to the Futures of Education Initiative. UNESCO Institute for Lifelong Learning. https://unesdoc.unesco.org/ark:/48223/pf0000374112 (03.03.2021).

Valk, Aune 2019. Tark ja tegus Eesti 2035. Kolme ekspertrühma visioonidokumentide kokkuvõte. https://www.hm.ee/sites/default/files/tark ja_tegus_eesti2035_kokkuvottev_visioonidokument.pdf (02.12.2020).

VL = Eduard Vääri, Richard Kleis, Johannes Silvet, Tiina Paet, Tuuli Rehemaa 2012. Võõrsõnade leksikon. 8., põhjalikult ümber töötatud trükk. Peatoim. Tiina Paet. Eesti Keele Instituut. Tallinn: Kirjastus Valgus. 


\title{
Nonformal learning in practitioners' language use
}

\author{
HALLIKI PÕLDA, \\ RIINA REINSALU, KATRIN KARU
}

The article discusses key concepts in the field of education - formal, informal and nonformal learning - and focuses on the latter. We identify the features of the concept of nonformal learning in the language use of practitioners and analyse how the main characteristics of nonformal learning and its varying terminology are expressed. Six focus group interviews carried out with practitioners who represented the fields of adult education, youth work, culture, well-being, economy, and environmental education comprised the material for analysis.

Qualitative content analysis revealed the learner's role in goal setting, his or her inner motivation and autonomy, variative learning environments and processes, the supportive role of the supervisor and the orientation of the learning process to the development of the learner as important characteristics of nonformal learning. Although all of these characteristics can be seen in other types of learning, in the case of nonformal learning the focus on the development and the responsibility of the learner and the practical nature of the learning was highlighted. In addition, it appeared that both nonformal and formal learning have clear commonalities and defining them through opposition is not justified.

As nonformal learning can take place in school and formal learning outside of it, the Estonian equivalent of formal learning as school learning is misleading in its meaning. The equivalent for non-formal learning - free learning ('vabaõpe') reflects voluntariness and freedom as an important characteristic of nonformal learning and is not associated with other types of learning. In the case of informal learning, experiential learning should be preferred over incidental learning ('juhuõpe'), as informal learning is based on experiences, not on chance.

The identified characteristics raise the question of whether the set of concepts that has been in place for the last 50 years is still appropriate today or whether the boundaries of formal and nonformal learning have become blurred, thus eliminating the need to distinguish them as different types of learning. This also reflects the need for additional studies.

Keywords: educational vocabulary, formal learning, informal learning, free learning, term, concept 
Halliki Põlda

Haridusteaduste instituut

Tallinna Ülikool

Narva mnt 25

10120 Tallinn

halliki.polda@tlu.ee

Riina Reinsalu

Eesti ja üldkeeleteaduse instituut

Tartu Ülikool

Jakobi 2

50090 Tartu

riina.reinsalu@ut.ee

Katrin Karu

Haridusteaduste instituut

Tallinna Ülikool

Narva mnt 25

10120 Tallinn

katrin.karu@tlu.ee 